\title{
IAMJ
}

INTERNATIONAL

AYURVEDIC

MEDICAL JOURNAL

\section{INERVENTIONS OF KANCHANAR GULGULU AND VARUNADI KASHAYAM IN SUBCLINICAL HYPOTHYROIDISM (SCH) - A CASE STUDY}

\begin{abstract}
Anita Renni
MD Ph.D, Professor \& HOD, Dept of Kayachikitsa, Mannam Ayurveda Co-Operative Medical College, Pandalam, Pathanamthitta (Dist.), Kerala, 689501
\end{abstract}

Corresponding Author: dranitarenni@gmail.com

https://doi.org/10.46607/iamj16p5012020

(Published online: November 2020)

Open Access

(C) International Ayurvedic Medical Journal, India 2020

Article Received: 00/09/2020 - Peer Reviewed: 00/10/2020 - Accepted for Publication: 00/10/2020

Check for updates

\begin{abstract}
SCH is defined as- Biochemical evidence of hypothyroidism (normal T3 \&T4 but raised TSH). SCH is likelihood of progression to clinical hypothyroidism. It may persist for years. It is more common in women than men, and its prevalence increases with age. Of patients with $\mathrm{SCH}, 80 \%$ have a serum TSH of less than $10 \mathrm{mlU} / \mathrm{L}$. The most important implication of SCH is high likelihood of progression to clinical hypothyroidism. The possibility that it is a cardiovascular risk factor has been a subject of debate. Currently the practical approach in modern therapy is routine levothyroxine therapy for persons with a persistent serum TSH of more than $10.0 \mathrm{mlU} / \mathrm{L}$ and individualized therapy for those with a TSH of less than $10.0 \mathrm{mlU} / \mathrm{L}$. There is no direct reference of thyroid in Ayurvedic classics, but the Galaganda and Gandamala have been frequently used in the text. According to Charakacharya presentation of multiple Granthi around the neck is called Gandamala and single swelling on the Parshva (laterals) of neck is Galagand. Galagand is explained classically in all the Ayurvedic texts, including Sushruta and Ashtangahruday, Since Galagand is the most untouched topic in Ayurveda and since thyroid is becoming one of the common problems in day- to-day practice. However, in recent times it has been observed that thyroid disorders can be very well managed with Ayurvedic drugs, although modern drugs are quite effective in getting TSH level down but with certain adverse effects. So, a case of Subclinical hyopothyroidism was selected and observed before, and after the treatment. Kanchanar is considered as a drug of choice for Granthi (Cysts)and Galagand
\end{abstract}


(Goitre), so here in this case Kanchanar Guggulu along with Varunadi Kashayam and Vaishwanar Choornam was administered for the purpose of Agnideepana (To improve digestive fire), \& Vatanulomana ( Regularise Vata). The patient was followed upto 6 months to observe increase in value of TSH.

Keywords: SCH, TSH, Galaganda Dhatwagni

\section{INTRODUCTION}

Thyroid is one of the earliest endocrine glands to build up $^{1}$. Subclinical hypothyroidism is characterized by a serum TSH above the upper reference limit with a normal free thyroxin (T4) level. This is only applicable when the hypothalamic-pituitary- thyroid axis is normal. It results from thyroid or suprathyroid abnormalities. Usually it runs a chronic course along with slow and insidious onset. At times patients are accidentally diagnosed when they come to seek treatment of other related problems or accompanying another person to a doctor. Thyroid gland abnormality influences body metabolism to a great extent and it also affects functioning of other glands. Thyroid hormone deficiency manifest as multi system involvement. Iodine is the trace element required for the synthesis of thyroid hormone. The daily requirement of iodine recommended is $150 \mathrm{ug} /$ day, when there is iodine deficiency. It is more prominent in females with ratio of male to female being 1:6. If left untreated it may result in severe complications with progressively increased mortality. The basic aim of treatment of $\mathrm{SCH}$ is to bring normalcy in TSH which reduces the incidence of clinical hypothyroidism and other complications also its affection towards other glands. The Colorado thyroid disease prevalence survey, conducted in United States of America on individuals who were not taking any thyroid hormones and who were attending a health fair tested with an upper normal TSH value of $5.0 \mathrm{mlU} / \mathrm{L}$ was used, reported a prevalence of $8.5 \%$ and $0.4 \%$ for subclinical and overt hypothyroidism respectively . ${ }^{2}$ In the British Whickham survey serum TSH values over $10 \mathrm{mlU} / \mathrm{L}$ were found in $9.3 \%$ of women and $1.2 \%$ of men.$^{3,4}$

With the changing lifestyle of $21^{\text {st }}$ century hypothyroidism is considered as one of the commonest diseases. Around 200 million population of the world is suffering from thyroid disorder. Presently the available treatment is orally artificially synthesized hormone Levothyroxine with main goal to normalize elevated TSH. So, there is need to search an effective management for this challenging disease.

In Ayurveda there is no exact mentioning of disease but it possibly can be correlate with Kaphaja Shopha (Swelling), Kaphaja Galaganda, Rasapradoshaja Vikaras (Disorders of Rasa Dhatu vitiation) Atisthoola purusha (Obesity). ${ }^{5}$ Although considering any of them the line of treatment remains same because on analysis of symptomatology of $\mathrm{SCH}$, in the light of ayurvedic principle of Dosha, and Dooshya showed in the disease, there is dominance of vitiated Kapha and Vata and vitiation of Rasadhatu (Component of body with nutrients and essence) and then Medadhatu (fat) is the main feature and somewhat similar pathology is seen in above mentioned diseases. As per Dosic predominance the Vataja type of Galaganda comparable to hyperthyroidism and Kaphaja and Medoja Galaganda to hypothyroidism in conventional system of medicine. In the pathogenesis Bhutagni, (Fire present in basic elements) Dhatwagni (Fire located inside the tissues), plays an important role, which shows the metabolic disturbances in this disease.

$\mathrm{SCH}$ sometimes has no symptoms, is especially true when TSH levels are only mildly elevated. When symptoms do arise, however, they tend to be vague and general. So, in Ayurveda there is wide scope of research to find out safety remedy for the management of SCH. Since there is predominantly vitiation of Vata and Kapha, so for their normalisation oral use of Kanchanar Guggulu, Varunadi Kashayam and Vaishwanar Choornam are taken into consideration.

A case study of a female patient aged $47 \mathrm{yrs}$ with Subclinical hypothyroidism was diagnosed and treated in the hospital of Mannam Ayurveda Co-operative Medical College, Pandalam, Pathanamthitta (Dist.), Kera- 
la. She complains Weight gain, Depression, Constipation, fatigue, hair loss, cold intolerance, swelling over feet since 2yrs. Examination revealed clinical features of Subclinical hypothyroidism with TSH $-8.3 \mathrm{mlU} / \mathrm{L}$, $\mathrm{Hb}-9.3 \mathrm{gm} \%$ and $\mathrm{T} 3, \mathrm{~T} 4$ within normal limits dated on 12-05-2017.

A treatment was planned to keep the disease and symptoms in mind. Tab Kanchanar Guggulu 2 BD with Varunadi Kashayam as an Anupan (Vehicle/ medium) in the dose of $15 \mathrm{ml}$ mixed with $45 \mathrm{ml}$. of warm water 1.5 hour before food. And Vaishwanar Choornam $5 \mathrm{gm}$ TDS with warm water $30 \mathrm{~min}$. before food. Patient was then advised to undergo TSH and $\mathrm{Hb}$ investigation after 1 month. After 1 month, patient started with the feeling of wellbeing and the intensity of the symptoms were reduced. Her TSH reduced to $6.5 \mathrm{mlU} / \mathrm{L}$, and then again, she was advised to continue same treatment for 1 month. Test was repeated on 1307-2017 and her TSH was $5.03 \mathrm{mlU} / \mathrm{L}, \mathrm{Hb}$ becomes $10.9 \mathrm{gm} \%$.

She was further observed for the period of 6 months where same medicines were advised along with Pathya and T3, T4 \& TSH investigations once in 3 months. These medicines help, maintained the T3, T4 $\&$ TSH level in normal range and patient was appearing normal clinically.

\section{DISCUSSION}

Subclinical hypothyroidism is defined as Biochemical evidence of hypothyroidism (normal T3 \&T4 but raised TSH). SCH is likelihood of progression to clinical hypothyroidism, which needs to be treated. A patient may land up to the complication's clinical hypothyroidism, obesity, cardiovascular diseases. Ayurvedic medicines takes time to normalize the value of $\mathrm{TSH}$, hence treat patiently. Since there is no direct reference of Subclinical / Clinical Hypothyroidism in the Ayurvedic texts, but Galagand or Gandamala is found in the text. Galagand is Vata kaphaja disorder hence the drugs used, act on Vata and Kapha. Kanchanar Guggulu is indicated in tumours, disorders of lymphatic channels, cyst, wounds, Gulma (Flatulance), skin disorders and Fistula, ${ }^{7}$ hence the drug was chosen. Ingredients of Kanchanar Guggulu have the effect of Deepana and the Shodhana of Sukshma srotasa (purification of microchannels). In this way by improving Koshthagni and Dhatwagni, it corrects tissue metabolism and by that way treated Subclinical hypothyroidism.

Varunadi Kashayam is used in Vatakaphaja disorder and it is also very well indicated in Gandamala, $\mathrm{Ka}$ pharogas, Medorogas, Agnimandya (Dyspepsia), Urustambha (Thigh spasticity), Shirashoola, Gulma and Antarvidradhi (Internal Abscess). ${ }^{8}$

According to Charakacharya Vatanulomana helps in relieving symptoms like Aruchi, Obesity, Pandu etc ${ }^{9}$. Vaishwanar Choornam was given for the purpose of Agnideepana, Vatanulomana. It is indicated in Amavata (Rheumatoid Arthritis), Gulma (Flatulence), Hridroga (Cardiac diseases), Vastjanya Rogas (Bladder disorders), Spleen diseases, Piles, Constipation Abdomen pain.${ }^{10}$ Since Galagand is Vatakaphaja disorder but with Pitta Dusti (Vitiation of Pitta Dosa), since there is hyposecretion of hormones Pitta to be considered as hormone and perhaps Pitta needs to be regularize to normalise the value of $\mathrm{TSH}$, hence combination was made.

\section{CONCLUSION}

This case demonstrates a classical presentation of Subclinical hypothyroidism which was responded well to the line of treatment mentioned in ayurveda, by giving positive variations in clinical \& biochemical findings.

The clinical trial highlights the following points:

1. Since Hypothyroidism is the second most prevalent disorder and should be ruled out at OPD level.

2. It can be very well managed with Ayurvedic medicines, depending upon the symptoms, careful selection of drugs to be made.

3. Ayurvedic treatment in the cases of subclinical hypothyroidism not only decrease the level of $\mathrm{TSH}$, but also stimulate the normal functioning of gland.

4. Significant improvement was found in both the parameters symptomatically as well as Pathologi- 
cally in the TSH level, which was $8.3 \mathrm{ml} \mathrm{U/L}$ before treatment was reduced to $5.03 \mathrm{ml} \mathrm{U} / \mathrm{L}$.

5. During the course of treatment, no adverse effects were seen.

6. Large scale, government- sponsored, multicentre, randomized, placebo- controlled studies are urgently needed to assess the efficacy of the above interventions in the patients having TSH levels of less than $10 \mathrm{mlU} / \mathrm{L}$ and more than $10 \mathrm{mlU} / \mathrm{L}$, to make a proper protocol for the disease modality and help the mankind with our ancient science.

7. Ayurveda medicines prove to be bliss in thyroid disorders, so it is therefore requested to prescribe Ayurvedic medicines for same.

\section{ACKNOWLEDGEMENT}

The author expresses her sincere gratitude to Dr. Thulaseedharan Nair, Managing Director, Mannam Ayurveda Co-operative Medical College, Pandalam, Kerala. The Author is thankful to the staff of Kayachikitsa department for their kind co-operation. Also, author is thankful to the patient for giving her consent and cooperation for this clinical trial.

\section{REFERENCES}

1. API Textbook of Medicine, $7^{\text {th }} 2003$ edition, published by the association of physician of India, pg no. 1051.

2. Canaris G J, Manovitz NR, Mayor G and Ridgeway EC, The Colorado Thyroid disease prevalence study, Arch Intern, Med, 160 (2000) 526534

3. Vanderpump M P, Tunbridge WM, French JM, et al., The incidence of Thyroid disorders in the community: a 20-year follow -up of the Wickham survey, Clin Endocrinol, 43 (1995) 55-68
4. Vanderpump MP, Tunbridge WM, Epidemiology and Prevention of clinical and subclinical hypothyroidism, Thyroid 12 (2002) 839-847

5. Sharma RS, Singh SK \& Rajoria K, Hypothyroidism an ayurvedic perspective, Aryavaidyan, 23 (4), 2010, 245-251

6. Sharangdhar Samhita by Sharangadharacharya Dipika Hindi commentary Madhyakhand Vatakakalpana adhyaya 7/ 95-98, edited by Brahmananda Tripathy, Chaukhamba Surbharathi Prakashana Varanasi, 2004 ,207

7. Sharagdhar samhita by Sharangdharacharya, Dipika hindi commentary, Madhyakhand Vatakakalpana adhyaya 7/99-100, edited by Brahmananda Tripathy, Chaukhamba Surbharathi Prakashana Varanasi, 2004, 207-208

8. Ashtangahrudaya, Shrimadvagbhattavirachitam, Edited with Vidyotini Hindi Commentary, Sutrasthana, Chapter 15/ 21-22, Shodhanadigansangraham, by Kaviraj Atridev Gupt, Chaukhamba Sanskrit Prakashan, 2005, 105-106

9. Agnivesha, Charaka, Dridhbala, Charaka Samhitha, Sutrasthana, Chikitsaprabhrutiya adhyaya $16 / 13-16$, edited by Ganga Sahaya Pandeya, $1^{\text {st }}$ Volume, Chaukhamba Sanskrit Prakashan Varanasi, 2006, 320-321

10. Chakradatta, Shrichakrapanidattavirachita, 'Vaidyaprabha' Hindi Commentary, Aamavata chikitsa Chapter 25/ 15-18, by Dr. Indradeva Tripathi, Edited by Prof. Ramanath Dwivedy, Chaukhambha Sanskrit Bhawan, Varanasi, Edition Reprint 2011, 167.

\section{Source of Support: Nil \\ Conflict of Interest: None Declared}

How to cite this URL: Anita Renni: Interventions Of Kanchanar Gulgulu And Varunadi Kashayam In Subclinical Hypothyroidism (Sch) - A Case Study. International Ayurvedic Medical Journal \{online\} 2020 \{cited November, 2020\} Available from: http://www.iamj.in/posts/images/upload/2641_2644.pdf 